\title{
PERMO-TRIASSIC EVOLUTION OF THE ADRIA MARGIN IN NORTHERN ALBANIA
}

\author{
Nota del m.e. MAURIZIO GAETANI (*)
}

(Adunanza del 26 marzo 2015)

SunTO. - Nell'Albania settentrionale e nell'adiacente Montenegro affiorano rocce che possono essere intrepretate come parti del margine orientale del promontorio di Adria verso l'Oceano della Neo-Tetide. Secondo le più recenti interpretazioni palinspastiche, la Piattaforma Dinarica è contornata durante il Triassico da aree a tendenza bacinale, quali Budva e Cukali. La zona di Cukali sarebbe adiacente alla zona di Korabi, che costituirebbe l'estremo lembo di litosfera continentale verso l'oceano. Le ofioliti della Zona della Mirdita, alloctone, traggono la loro origine dalla fascia di litosfera oceanica del Vardar. L'oceano della Neo-Tetide iniziò ad aprirsi lungo il margine di Adria nelle Albanidi nell'Anisico superiore (Triassico medio).

$* * *$

ABSTRACT. - In the northern Albania and surrounding Montenegro are cropping out rocks that may be referred to the eastern margin of Adria promontory, facing the NeoTethys Ocean. According to present palinspasthic interpretation, the Dinaric Platform is surrounded by areas (Budva and Cukali zones) with basinal trend during the Triassic. The Cukali zone in this interpretation is situated nearby the Korabi zone, who represents the easternmost sector of continental lithosphere towards the ocean. The ophiolites of the Mirdita zone are allochtonous and originate from the oceanic lithosphere of Vardar. The early opening of the Neo-Tethys Ocean along this sector of the Adria margin is dated to the late Anisian (Middle Triassic).

(i) Istituto Lombardo Accademia di Scienze e Lettere, Milano, Italy.

E-mail: info@istitutolombardo.it 


\section{INTRODUCTION}

Albania and surroundings areas contains good exposures to analyse the Permian and Triassic evolution of the Adria continental margin. A cross-section may be restored west to east. Moving from the zones of Adriatic Carbonate Platform and Budva, cropping out in the nearby Montenegro, the section go through the Dinaric Carbonate Platform exposed in the Albanian Alps, the Cukali and Korabi zones, and the distal part of the continental margin preserved in the sole of the Mirdita nappe, with its original source in the Vardar zone and its ophiolites.

\section{THE ISOPIC ZONES (Fig. 1)}

\subsection{Adriatic Carbonate Platform/Kruja zone}

Oldest rocks cropping out near the island of Vis are referred to the Middle Triassic Porphyrite-Chert Formation (Radoicic \& D’Argenio 1999; Tari 2002). They are overlain by anhydrites possibly of Carnian age, in turn followed by peritidal dolostone of the Lisani Supersequence (Čadjenović et al. 2008) of Norian age.

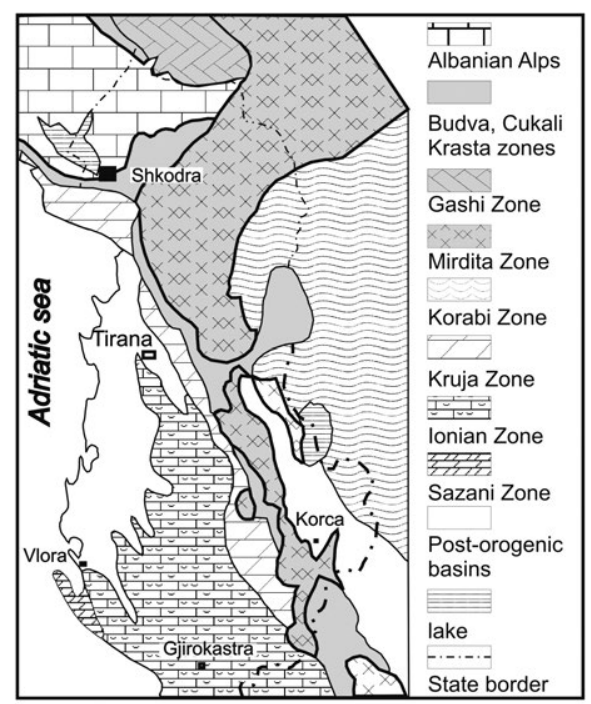

Fig. 1 - Index map. 


\subsection{Budva zone}

Recognized first by Bukowski (1927) as Budva-Cukali, it was always considered as a basin-prone area, with older outcrops of Early Triassic age (Dimitrijević 1997). However, recently Krystyn et al. (2014) reported the presence of Upper Permian deep-water sediments with conodonts, pushing back to the latest Palaeozoic the evidence for the existence of a basinal succession.

Bottom to top the succession is as follows:

- Uppermost Permian. Mixture of bioclastic layers and fine grained siliceous sponge bearing wackestone of deeper water character (Krystyn et al. 2014).

- Lower Triassic. Sandstone, marl, dolostone and oolitic limestone; thickness of about $200 \mathrm{~m}$ (Dimitrijević 1997). The age of overlaying "Anisian Flysch" of Dimitrijević M. (1967) should be reconsidered, being possibly Early Triassic in age (Gaetani et al. 2015).

- Middle Triassic. With the incepting of Anisian, terrigenous inputs decreased and volcanics outpoured (basalts overlain by andesites and dacites). Bulog Limestone locally occurs as well as radiolarites and cherty limestone, with a total thickness around $200 \mathrm{~m}$.

- Upper Triassic. Cherty limestone with Halobiids and conodonts (Cafiero \& De Capoa Bonardi 1980 a,b).

\subsection{Albanian Alps}

They represents the southern tip of the Karst Zone (Auboin et al. 1970), presently known as Dinaric Carbonate Platform or included in the wider Adriatic/Dinaric Carbonate Platform (Karst Zone/ Dinaric Carbonate Platform (Auboin et al. 1970; Dimitrijevic MD 1997; Radoicic and d'Argenio 1999; Gawlick et al. 2012). They stratigraphy has been recently revised (Gaetani et al. 2015).

Bottom to top, the succession is as follows.

- Middle Permian. Shallow water massive calcarenite, with fusulinids, microproblematica, and occasionally conodonts. Severely disrupted by tectonics, thickness at least 100-150 m.

- Upper Permian. Presently not recognized.

- Lower Triassic. Very thick succession of shale and siltstone, with four major conglomerate intercalations. Locally, oolitic limestone lenses. Thickness not less than $500 \mathrm{~m}$. 
- Middle Triassic. During the Anisian the area was gradually transgressed by a carbonate ramp, with initially still some shaly intercalations. The ramp drowned to deeper condition around the boundary Pelsonian/Illyrian (i.e. middle to late Anisian). Some volcanic effusion occurred nearby, but no lavas have been detected, only tuffitic layers are intercalated in the cherty limestones. Towards the end of the Ladinian, sediments gradually filled the basinal area and the carbonate platform spread over all the area, continuing for the remaining part of Triassic,

- Only during the earliest Carnian, locally an intraplatform depression was filled by black limestone and dolostone, with slumpings and breccias, testifying to still active extensional movements.

\subsection{Cukali Zone}

The outcropping succession starts with debris flows (few tens of $\mathrm{m}$ thick) with semiconsolidated blocks containing middle Anisian (Pelsonian) foraminifers (Theodhori 1988; Meço and Aliaj 2000). It is overlain by a succession suggesting the drowning to deep waters during the late Anisian and continues in open sea conditions through the whole Triassic (Gjata et al. 1987; Theodhori 1988; Marcucci et al. 1994; Chiari et al. 1996; Meço and Aliaj 2000). Volcanics outpouring is also Middle Triassic. Meço (2005, text-fig. 10) quotes a section in which Norian platy limestone are tectonically overlying thick limestone with fusulinids of Permian age. Is this an evidence that Cukali zone was in shallow water conditions during the Permian or is just a block fallen in the basin from the margin of the carbonate platform?

The overall picture for the Cukali Zone is therefore of an area that was already in basinal conditions at least since the Anisian and continued in basinal condition through all the Triassic.

\subsection{Korabi Zone}

A very complex zone because of the heavy tectonics dismembering the zone, due to the overthrusting movements of the Mirdita above the Korabi (Collaku et al. 1992). Several subzones have been detected, in which Palaeozoic sediments are prevailing. According to Meço and Aliaj (2000) in the Caja subzone, the Devonian succession 
is unconformably covered by about $100 \mathrm{~m}$ of conglomerate and sandstone (?Permian/Triassic), in turn overlain by up to $400 \mathrm{~m}$ thick sandstone to pelitic successions with limestone intercalations, bearing Olenekian/early Anisian conodonts. No younger Triassic rocks are known from that area (Meço and Aliaj 2000). In the Korabi Highland subzone, instead, a mostly terrigenous Lower Triassic is overlain by a mixed volcanic/carbonatic succession, with platy and cherty limestone of open sea environment. Ladinian and Carnian conodonts have been etched out (Meço 2010).

\subsection{Mirdita Zone}

In the marginal area of the Mirdita Zone it crops out the Rubik Complex, also named sub ophiolite mélange (Bortolotti et al. 2005). Within the blocks forming the sole of the nappe, slabs of OlenekianMiddle Triassic succession are recognized in many places (Kçira, Qerreti, Rubiku, Miraka among others) (Shallo 1992; Kellici and de Wever 1994; Muttoni et al. 1996; Chiari et al. 1994, 1996; Germani 1997; Gawlick et al. 2008). The pelagic deposition started in the Spathian (late Olenekian) (Muttoni et al. 1996; Germani 1997), and volcanics outpoured since the middle Anisian, with picritic basalts as pillow-lava. Evidence of new oceanic crust starts from the late Anisian (Chiari et al. 1996; Gawlick et al. 2008).

Ophiolite units thrust on the Rubik complex. In the ophiolites are recognized Western and Eastern units, according to their geological and petrochemical features (Shallo 1992; Beccaluva et al. 1994; Bortolotti et al. 1996, 2006). The Western unit is characterized by thrust slices including, bottom to top, the metamorphic sole, lherzolitic mantle tectonites, mafic-ultramafic cumulates, a discontinuous sheeted dyke complex, and a volcanic sequence (Beccaluva et al. 1994; Saccani et al. 2004). The volcanic sequence is the most spread (Nicolas et al. 1999).

The Eastern unit shows a sequence up to $10 \mathrm{~km}$ thick, including, at the base, harzburgitic mantle tectonites with well-developed metamorphic sole at their base, a thick intrusive sequence, a sheeted dyke complex and a volcanic sequence (Shallo 1992; Beccaluva et al. 1994; Bortolotti et al. 2006; Saccani et al. 2004). 


\section{CONCLUSIONS}

The geological evolution summarized in the previous chapter may be interpreted as the evolution of a continental margin that underwent extensional movements (Figs. 2 and 3). These rifiting movements were active during latest Middle Permian, Early Triassic (mostly Olenekian), and around the boundary Pelsonian/Illyrian (i.e. middle/late Anisian). The acme of the extensional movements was reached during the Olenekian. However, it cannot be excluded that a transcurrent component was active during the Olenekian. Could we start to consider the Scutari-Pec transversal zone (Dercourt 1967) in some way already active during the Early Triassic? In a single ocean model, the extension is strictly related to the incepting of oceanization that started in the Middle Triassic (Bortolotti et al. 2005; Gawlick et al. 2008; Xhomo et al. 2008, amongst others).

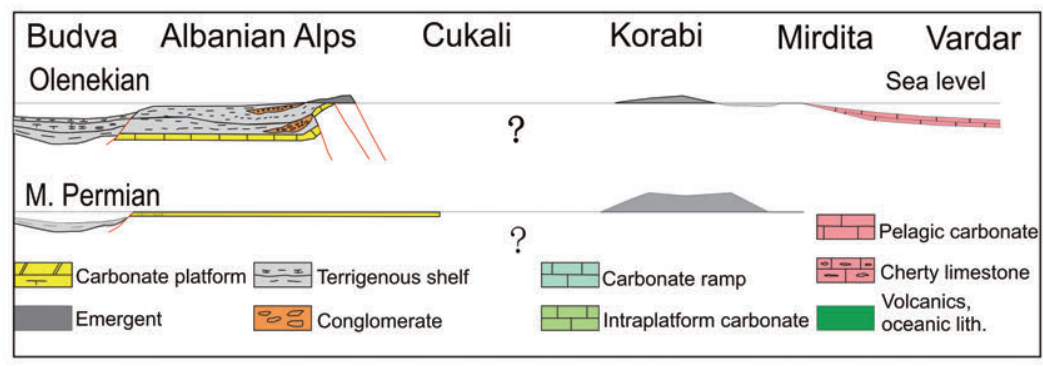

Fig. 2 - Palinspastic interpretation of the Adria margin evolution from Middle Permian to Early Triassic

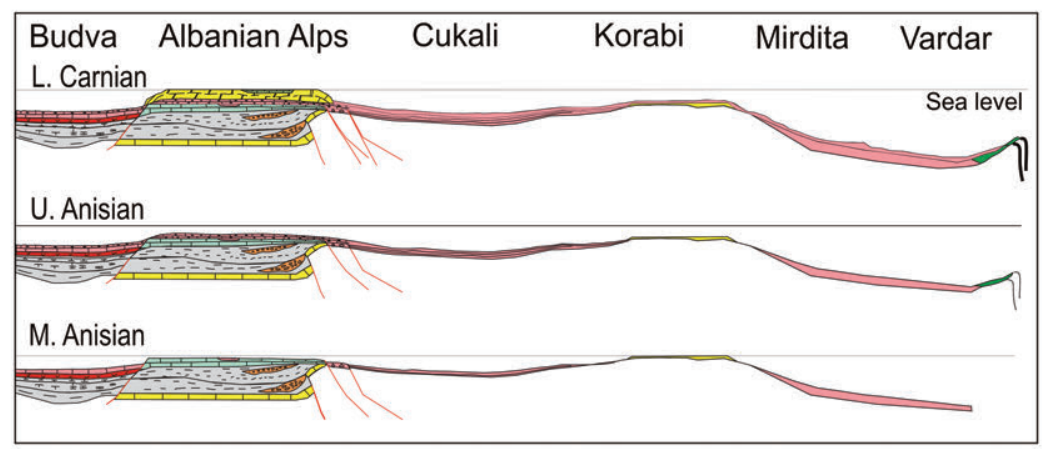

Fig. 3 - Palinspastic interpretation of the Adria margin evolution from Middle Triassic to earliest Carnian. 


\section{REFERENCES}

Auboin, J., Blanchet, R., Cadet, J-P., Celet, P., Charvet, T., Chorowicz, T., Cousin, M. and Rampnoux, J-P. 1970. Essai sur la géologie des Dinarides. Bulletin de la Societé Géologique de France (7) 12, 1060-1095.

Beccaluva L., Coltorti M., Premiti I., Saccani E., Siena F. \& Zeda O. 1994. Mid-ocean ridge and supra-subduction affinities in ophiolitic belts from Albania. Ofioliti 19, 77-96.

Bortolotti, V., Kodra A., Marroni M. et al. 1996. Geology and petrology of the ophiolitic sequences in the Mirdita region, northern Albania. Ofioliti 21, 3-20.

Bortolotti, V., Marroni, M., Pandolfi, L. and Principi, G. 2005. Mesozoic to Tertiary tectonic history of the Mirdita ophiolites, northern Albania. The Island Arc, 14, 471-493.

Bortolotti, V., Chiari, M., Kodra, A., Marcucci, M., Marroni, M., Mustafa, F., Prela, M. Pandolfi L., Principi, GF. Saccani E. 2006. Triassic MORB magmatism in Southern Mirdita (Albania). Ofioliti, 31, 1-9.

Bukowski, G., 1927. Geologishe Detailkarte des Gebirge um Budua. Jabrbuch der geologischen Bundesanstalt, Wien, 57, 1-2: 195-204.

Cafiero B. \& De Capoa Bonardi P. (1980a). I conodonti dei calcari ad Halobia del Trias superiore del Montenegro (Crna-Gora, Jugoslavia). Rivista It. Paleont. Strat., 86/3: 563-576.

Cafiero B. \& De Capoa Bonardi P. (1980b). Stratigraphy of the pelagic Triassic in BudvaKotor area (Crna Gora, Yougoslavia). Boll. Soc. Paleont. Ital., 19/2: 179-204.

Čadjenović D., Kilibarda Z., Radulović N. (2008) - Late Triassic to Late Jurassic evolution of the Adriatic Carbonate Platform and Budva Basin, Southern Montenegro. Sedimentary Geology, 204 : 1-17.

Chiari, M., Marcucci, M. and Prela, M. 1994. The Mirdita Ophiolite project: 2. The Radiolarian assemblage in the cherts at Fushe Arrez and Shabaj (Mirdita area, Albania). Ofioliti, 19, 313-318.

Chiari, M., Marcucci, M., Cortese, G., Ondrejiçkova, A. and Kodra, A. 1996. Triassic radiolarian assemblages in the Rubik area and Cukali Zone, Albania. Ofioliti 21, 77-84

Collaku, A., Cadet, JP., Bonneau, M. and Jolivet, L. 1992. L'difice structural de l'Albanie Septenrionale: Des éléments de réponse sur la modalité de mise en place des ophiolites. Bulletin de la Societé Géologique de France, 163, 455-468.

Dercourt, J. 1967. Sur l'accident de Scutari-Pec, la signification paléogeographique de quelques series condensées en Albanie septentrionale. Annales de la Societé Géologique du Nord, 9, 1-109.

Dimitrijević, MN. 1967. Sedimentološko-stratigrafski problemi srednjotriaskog fliša u terenima izmedu Skadarskog jezera i Jadranskog mora (Sedimentologic problems of Middle Triassic flysch in the terrains between Scutari Lake and the Adriatic Sea). Geološki glasnik, Zavod za geološka istrazivanja Crne Gore, 5, 223-311.

Dimitrijević, MD. 1997. Geology of Yugoslavia. Geological Institute Gemini, Belgrade, $1-187$.

Gaetani M., Meco S., Rettori R., Henderson C.M., Tulone A. (2015) - The Permian and Triassic in the Albanian Alps. Acta Geologica Polonica, 56/2 Acta Geologica Polonica, 65, 271-295. 
Gawlick, H-J., Frisch, W., Hoxha, L., Dumitrica, P., Krystyn, L., Lein, R., Missoni, S. and Schlagentweit, F. 2008. Mirdita Zone ophiolites and associated sediments in Albania reveal Neotethys ocean origin. International Journal Earth Sciences, 97, 865-881.

Gawlick, H-J., Gorican, S., Missoni, S. and Lein, R. 2012. Late Anisian platform drowning and radiolarite deposition as a consequence of the opening of the Neotethys ocean (High Karst nappe, Montenegro). Bulletin de la Societé Géologique de France, 183, 349-358.

Germani, D. 1997. New data on ammonoids and biostratigraphy of the classic Spathian Kçira sections (Albania). Rivista Italiana di Paleontologia e Stratigrafia, 103, 267 292.

Gjata, Th., Theodhori, P., Kici, V., Marku, D., Pirdeni, A., Kanani, J., Dodona, E. and Zeraj, I. 1987. Stratigrafia dhe kushtet e formimit të depozitimeve triasike në Albanidet Lindore. Buletin i Shkencave Gjeologiike, 2, 79-90.

Kellici, I. and de Wever, P. 1994. Ouverture triasique du bassin de la Mirdita (Albanie) révélée par les radiolaires. C.R. Academie Sciences Paris, 318, 1669-1676.

Krystyn, L., Đaković, M., Horacek, M., Lein, R., Cadenović, D., Radulović, N. 2014. Pelagically influenced Late Permian and Early Triassic deposits in Montenegro: remnant of Internal Dinarid Neotethys or Paleotethys relict? Berichte Institut Erdwissenshaften K.-F.-Univ. Graz, 20/1, 114.

Marcucci, M., Kodra, A., Pirdeni, A. and Gjata, Th. 1994. Radiolarian assemblages in the Triassic and Jurassic cherts of Albania. Ofioliti, Special Issue on "Albanian ophiolites, state of the art and perspectives" (Beccaluva Ed), 19, 105-114.

Meço, S. 1999. Conodont biostratigraphy of Triassic Pelagic strata, Albania. Rivista Italiana di Paleontologia e Stratigrafia, 105, 251-266.

Meço, S. 2005. Upper Triassic conodonts and lithofacies from Albania. Geologica et Palaeontologica, 39: 35-53.

Meço, S. 2010. Litho-biostratigraphy and conodonts of Palaeozoic/Triassic deposits in Albania. Palaeontographica, Abt. A, 290, 131-197.

Meço, S. and Aliaj, S. 2000. Geology of Albania. 246 pp, Gebrueder Borntraeger, Berlin. Muttoni, G., Kent, DV., Meço, S., Nicora, A., Gaetani, M., Balini, M., Germani, D. and Rettori, R. 1996. Magneto-biostratigraphy of the Spathian to Anisian (Lower to Middle Triassic) Kçira section, Albania. Geophysical Journal International, 127, 503-514.

Nicolas A., Boudier F. \& Meshii A. 1999. Slow spreading accretion and mantle denudation in the Mirdita ophiolite (Albania). Journal of Geophysical Research 104, 15 $155-67$.

Radoicic, R. and d'Argenio, B. 1999. An outline of the geology of the External Dinarides and their Mesozoic-Early Tertiary facies. Rendiconti Accademia Scienze Fis. Mat. Napoli, 64, 181-243.

Saccani E., Beccaluva L., Coltorti M. \& Siena F. 2004. Petrogenesis and tectono-magmatic significance of the Albanide-Hellenide Subpelagonian ophiolites. Ofioliti 29, 75-93.

Shallo, M. 1992. Geological Evolution of the Albanian ophiolites and their platform 
periphery. Geologisches Rundschau, 81, 681-694.

Tari V. 2002. Evolution of the northern and western Dinarides: a tectonostratigraphic approach EGU Stephan Mueller Special Publication Series, 1, 223-236, 2002. European Geosciences Union

Theodhori, P. 1988. Kushtet e sedimentimit dhe evolucioni paleogjeografik mesozoik ne Nenzonen e Cukalit. 183 pp. Sherbimi Gjelogjik Shqiptar,Tirana. [unpublished]

Xhomo, A., Kodra, A. Xhafa, Z., Shallo, M., (Eds) 2008. Gjelogjia e Shqiperise. Stratigrafia, Magmatizmi, Metamorfismi, Tektonika, Neotektonika,Evolucioni Paleogjeografik dhe Gjeodinamik. 464 pp., Sherbimi Gjelogjik Shqiptar, Tirana. 
